\title{
Improvement of Social Science Learning Achievement With A Scientific Approach Assisted With The Zoom Meeting Application in Class IV Primary School
}

\author{
Imron Ade Irawan
}

SD Negeri Cilacap 05

Imronirawan89@gmail.com

\author{
Article History \\ accepted 14/11/2020
}

\begin{abstract}
The purpose of this classroom action research is to improve social studies learning outcomes through the Scientific Approach assisted by the Zoom Meeting Application. The subjects in this study were fourth grade students of SD Negeri Cilacap 05, with 29 children. This research was conducted in grade IV SD Negeri Cilacap 05, Korwil for Education, Cilacap Selatan, Cilacap Regency. This research was conducted in the 1st semester of the 2020/2021 school year, lasting for 3 weeks starting from the 4th week of October 2020 to the 2nd week of November 2020. The number of students who completed studying in the Pre-Cycle was only 10 children or $34 \%$ and students 19 children or $66 \%$ have not yet completed. In Cycle I student learning outcomes increased with an average score of 73.27. Students who completed learning were 21 children or $72 \%$. Then in Cycle II there was a slight increase in student learning outcomes, namely 23 students who completed learning or $79 \%$. Based on the description above, it is concluded that applying the Scientific Approach and assisted by the Zoom Meeting Application in the social studies learning process can improve the learning outcomes of fourth grade students of SD Negeri Cilacap 05. So, the hypothesis that the author proposes in this classroom action research is truly proven
\end{abstract}

Keywords: learning outcomes, scientific approach, zoom meeting application

\begin{abstract}
Abstrak
Tujuan penelitian tindakan kelas ini adalah meningkatkan hasil belajar IPS melalui Pendekatan Saintifik berbantuan Aplikasi Zoom Meeting. Subjek dalam penelitian ini adalah siswa kelas IV SD Negeri Cilacap 05, dengan jumlah peserta didik ada 29 anak. Penelitian ini dilaksanakan di kelas IV SD Negeri Cilacap 05, Korwil Bidang Pendidikan Cilacap Selatan Kabupaten Cilacap. Penelitian ini dilaksanakan pada semester 1 tahun pelajaran 2020 / 2021, berlangsung selama 3 minggu mulai dari minggu ke 4 bulan Oktober 2020 sampai dengan minggu ke 2 bulan Nopember tahun 2020. Jumlah siswa yang tuntas belajar pada Pra Siklus hanya 10 anak atau $34 \%$ dan siswa yang belum tuntas berjumlah 19 anak atau $66 \%$. Pada Siklus I hasil belajar siswa meningkat dengan nilai rata-rata menjadi 73,27. Siswa yang tuntas belajar sebanyak 21 anak atau $72 \%$. Kemudian pada Siklus II terjadi sedikit peningkatan hasil belajar siswa yaitu siswa yang tuntas belajar sebanyak 23 anak atau $79 \%$. Berdasarkan uraian di atas, maka ditarik kesimpulan bahwa dengan menerapkan Pendekatan Saintifik dan berbantuan Aplikasi Zoom Meeting dalam proses pembelajaran IPS dapat meningkatkan hasil belajar siswa kelas IV SD Negeri Cilacap 05. Jadi, hipotesis yang penulis ajukan dalam penelitian tindakan kelas ini benar-benar terbukti
\end{abstract}

Kata kunci: hasil belajar, pendekatan saintifik, aplikasi zoom meeting

Social, Humanities, and Education Studies (SHEs): Conference Series https://jurnal.uns.ac.id/shes

p-ISSN 2620-9284 e-ISSN 2620-9292 


\section{PENDAHULUAN}

Selama enam bulan terakhir, Pandemi COVID-19 menjadi musibah yang luar biasa. Yang terjadi hampir di seluruh negara tanpa terkecuali, termasuk negara Indonesia. Pemerintah dalam hal mencegah penyebaran penularan virus Covid-19 mengeluarkan Keputusan Menteri Kesehatan Republik Indonesia Nomor HK. 01.07 / MENKES / 413 / 2020 Tentang Pedoman Pencegahan dan Pengendalian Corona Virus Disease 2019 (COVID-19) . Hal yang serupa juga dilakukan oleh Menteri Pendidikan Nasional dengan mengeluarkan SE Nomor 36962 / MPK.A / HK / 2020, tentang Pembelajaran Secara Daring dan Bekerja dari Rumah Dalam Rangka Pencegahan Penyebaran Corona Virus Disease ( COVID-19). Dalam situasi pandemi seperti ini guru dan peserta didik dituntut mempunyai kemampuan dalam mengoperasikan gadget berupa HP, Android, dan laptop sebagai alat utama pembelajaran daring. Guru sebagai pendidik harus tetap menyampaikan pembelajaran kepada peserta didik agar hak pembelajaran yang sebagaimana mestinya. Pada kenyataannya pembelajaran daring belum maskimal, yang dikarenakan kondisi sarana dan prasarana serta kemampuan mengoperasikan aplikasi dari Guru dan peserta didik. Jumlah kepemilikan Hand Phone Android di kelas IV SD Negeri Cilacap 05 adalah dari 29 peserta didik, yang memiliki secara pribadi berjumlah 8 anak selebihnya milik orang tua atau wali mereka. Guru sebagai pendidik juga masih kurang ahli dalam penggunaan aplikasi dalam pembelajaran daring. Sebagian besar guru hanya menggunakan aplikasi Whatsapp Grup dalam pelaksanaan pembelajaran dan mengerjakan soal-soal yang ada pada buku pendamping dengan sistem satu arah tanpa pendampingan guru. Peserta didik hanya didampingi orang tua sebagai sosok pengganti guru dalam menjelaskan konsep. Hal tersebut menjadikan hasil belajar peserta didik mengalami penurunan khususnya pada Muatan Pelajaran IPS pada Tema 3 Subtema 3 Pembelajaran 1 yaitu materi tentang "Pemanfaatan Lingkungan Alam Hayati". Terlihat dari hasil rata-rata evaluasi yang dicapai peserta didik masih di bawah KKM yakni dari jumlah seluruh siswa yang lulus KKM hanya 34\%. Oleh karena, itu perlu dilakukan perbaikan pada proses pembelajaran sehingga hasil prestasi belajar peserta didik dapat tercapai sesuai dengan tujuan pembelajaran. Salah satu upaya yang bisa dilakukan oleh guru selaku pendidik untuk meningkatkan hasil belajar peserta didik terutama pada muatan pelajaran IPS pada masa pandemi seperti sekarang ini yaitu dengan berbantuan aplikasi Zoom Meeting dengan Pendekatan Saintifik. Faktor yang mempengaruhi prestasi hasil belajar peserta didik adalah minat dan motivasi belajar. Dengan adanya minat dan motivasi, peserta didik akan belajar lebih keras, ulet, tekun, dan memiliki konsentrasi penuh dalam proses pembalajaran daring. Adapun wujud operasional dari Pendekatan Saintifik adalah adanya penyelidikan ilmiah. Penyelidikan ilmiah ini didefinisikan sebagai usaha sistematik untuk mendapatkan jawaban atas masalah atau pertanyaan. Dengan demikian, ciri khas Pendekatan Saintifik adalah adanya pemecahan masalah melalui penalaran dan pengamatan. Sehingga peneliti ingin menerapkan Pendekatan Saintifik sebagai obat yang sesuai dengan permasalahan yang terjadi di SD Negeri Cilacap 05 Kecamatan Cilacap Selatan, kabupaten Cilacap. Penilaian hasil belajar oleh pendidik adalah proses pengumpulan informasi atau bukti tentang capaian pembelajaran peserta didik dalam kompetensi sikap spiritual dan sikap sosial, kompetensipengetahuan, dan kompetensi keterampilan yang dilakukan secara terencana dan sistematis, selama dan setelah proses pembelajaran (Warso, 2017: 124). Dari berbagai pendapat para ahli mengenai hasil belajar, dapat disimpulkan bahwa hasil belajar adalah pencapaian indikator peserta didik telah mengikuti rangkaian proses pembelajaran dengan hasil yang sesuia dengan apa yang sudah diserap dalam pembelajaran. Pendidikan IPS di SD harus memperhatikan kebutuhan anak yang berusia antara 6-12 tahun. Anak dalam kelompok usia 7-11 tahun menurut Piaget (1963) berada dalam perkembangan kemampuan intelektual/kognitifnya pada tingkatan operasional konkret. Mereka 
memandang dunia dalam keseluruhan yang utuh atau holistik. Mereka juga belum memahami konsep yang abstrak, yang mereka pedulikan adalah hal yang konkret. Padahal bahan materi IPS penuh dengan pesan-pesan yang bersifat abstrak. Konsepkonsep seperti manusia, lingkungan, waktu, perubahan, kesinambungan, keragaman sosial, ekonomi, budaya adalah konsep-konsep abstrak yang dalam program studi IPS dibelajarkan kepada peserta didik SD. Pendekatan saintifik adalah suatu proses pembelajaran yang dirancang supaya peserta didik secara aktif mengkonstruk konsep, hukum, atau prinsip melalui kegiatan mengamati, merumuskan masalah, mengajukan/merumuskan hipotesis, mengumpulkan data dengan berbagai teknik, menganalisis data, menarik kesimpulan, dan mengkomunikasikan (M. Hosnan, 2014 :34). Pendekatan saintifik dimaksukan untuk memberikan pemahaman kepada peserta didik dalam mengenal, memahami berbagai materi menggunakan pendekatan ilmiah. Penerapan pendekatan saintifik dalam pembelajaran melibatkan keterampilan proses seperti mengamati, mengklasifikasi, mengukur, meramalkan, menjelaskan, dan menyimpulkan. Aplikasi Zoom Meeting adalah aplikasi buatan miliarder, Eric Yuan, yang dirilis pada Januari 2013. Selain aplikasi, Zoom juga dapat diakses melalui website, baik untuk OS Mac, Windows, Linux, iOS, dan Android. Zoom Cloud Meeting adalah sebuah aplikasi yang dapat menunjang kebutuhan komunikasi di manapun dan kapanpun dengan bayak orang tanpa harus bertemu fisik secara langsung. Aplikasi Zoom Cloud Meetings adalah sebuah aplikasi yang memungkinkan seorang host untuk membuka sebuah ruang virtual dan mengundang participants untuk turut mengikuti kegiatan berupa presentasi, rapat dan pembelajaran di ruang tersebut. Dalam ruang virtual bernama meeting tersebut, host maupun participants juga bisa saling membagikan file, baik berupa gambar maupun video. Berdasarkan latar belakang yang dikemukakan di atas, maka permasalahan yang perlu dicari solusinya adalah "Bagaimana Penerapan Pendekatan Saintifik Berbantuan Aplikasi Zoom Meeting dapat Meningkatkan Hasil Belajar IPS Muatan dari Tema 3 pada Peserta Didik Kelas 4 SD Negeri Cilacap 05, Kecamatan Cilacap Selatan Kabupaten Cilacap Tahun Ajaran 2020/2021?". Adapun tujuan dari penelitian tindakan kelas ini adalah Meningkatkan hasil belajar IPS muatan pelajaran dari Tema 3 melalui penerapan Pendekatan Saintifik berbantuan Aplikasi Zoom Meeting pada peserta didik kelas 4 SD Negeri Cilacap 05 Kecamatan Cilacap Selatan Kabupaten Cilacap Tahun Ajaran 2020/2021.

\section{METODE}

Subjek dalam penelitian ini adalah peserta didik kelas IV SD Negeri Cilacap 05 Kecamatan Cilacap Selatan Kabupaten Cilacap tahun pelajaran 2020 / 2021 semester 1 dengan jumlah peserta didik ada 29 anak yang terdiri dari 16 peserta didik laki - laki dan 13 peserta didik perempuan. Usia siswa kelas VI ini berkisar 10 sampai 11 tahun. Secara keseluruhan keadaan fisik peserta didik kelas IV SD Negeri Cilacap 05 adalah baik. Latar belakang pekerjaan orang tua peserta didik mayoritas adalah nelayan karena lingkungan sekolah kami di pesisir pantai. Penelitian ini dilaksanakan di kelas IV SD Negeri Cilacap 05, Korwil Bidang Pendidikan Cilacap Selatan Kabupaten Cilacap, yang berlokasi di jalan Kol.Sugiono No.02, Kecamatan Cilacap Selatan, Kabupaten Cilacap. Penelitian ini dilaksanakan pada semester 1 tahun pelajaran 2020 / 2021, berlangsung selama 3 minggu mulai dari minggu ke 4 bulan Oktober 2020 sampai dengan minggu ke 2 bulan Nopember tahun 2020 dengan rincian per siklusnya akan dilakukan dua kali siklus untuk satu pertemuan akan diambil selama 70 menit. Langkah-langkah dalam siklus akan terdiri dari empat tahapan yaitu perencanaan pembelajaran, pelaksanaan pembelajaran, kegiatan observasi, dan kegiatan refleksi. 


\section{HASIL DAN PEMBAHASAN}

Hasil belajar IPS peserta didik kelas 4 SD Negeri Cilacap 05 sebelum dilaksanakan Penelitian Tindakan Kelas masih banyak peserta didik yang hasil belajarnya belum tuntas. Ketuntasan klasikal belajar peserta didik kelas 5 pada pembelajaran IPS hanya 34\%. Hasil ini belum sesuai dengan tujuan yang akan dicapai pada setiap Kriteria Ketuntasan Minimal (KKM) atau jauh dari ketuntasan belajar pada muatan pembelajaran IPS yaitu 70 . Kondisi awal dapat diketahui bahwa dari total jumlah peserta didik yaitu 29 anak, diketahui prosentase ketuntasan hanya 34\% dari 29 peserta didik. Sedangkan, 19 peserta didik lainnya mendapat nilai di bawah KKM dengan prosentase $66 \%$, dan dinyatakan tidak tuntas pada muatan pelajaran IPS. Pada kondisi awal, nilai rata-rata yang diperoleh adalah sebesar 67,65 , dengan nilai tertinggi 80 dan nilai terendah 30. Berdasarkan kondisi inilah, maka diperlukan sebuah penelitian tindakan kelas dengan tujuan untuk meningkatkan hasil belajar IPS Tema 3 pada peserta didik kelas IV SD Negeri Cilacap 05 melalui pendekatan Pembelajaran Saintifik dengan berbantuan aplikasi Zoom Meeting. Kemudian untuk analisis data hasil belajar prasiklus, peneliti jadikan sebagai data sampel penelitian. Penelitian Tindakan Kelas ini akan dilaksanakan dalam 2 siklus dan setiap siklus dilakukan 1 kali pertemuan dengan penerapan Pendekatan Pembelajaran Saintifik dengan berbantuan aplikasi Zoom Meeting dalam pembelajaran IPS Tema 3. Lalu untuk kegiatan praktek pembelajaran di masing-masing siklus akan dilaksanakan selama 2×35 menit menggunakan aplikasi Zoom Meeting. Rencana kegiatan perbaikan pembelajaran pada Siklus I di Kelas IV SD Negeri Cilacap 05 untuk muatan pelajaran IPS Tema 3 materi "Pemanfaatan Sumber Daya Alam Hayati" dilaksanakan dengan menggunakan Rencana Pelaksanaan Pembelajaran (RPP) Daring untuk alokasi waktu 2×35 menit, yang dilengkapi dengan Lembar Observasi Sikap ketika belajar dari rumah, LKPD, lembar evaluasi (Kahoot), dan Media Pembelajaran (Power Point yang berupa gambargambar). Tahap pelaksanaan tindakan siklus I ini dilaksanakan dalam satu kali pertemuan, dengan alokasi waktu adalah 2 x 35 menit. Perbaikan pembelajaran ini dilaksanakan pada hari Senin, 2 November 2020. Kegiatan yang dilakukan untuk mengawali pembelajaran pada siklus I memakai aplikasi whatsapp group dan zoom meeting, untuk mempermudah peneliti dalam menyampaikan ke seluruh peserta didik. Adapun kegiatannya seperti membuka pelajaran dengan salam, berdoa bersama, mengabsen siswa, meminta siswa untuk selalu menerapkan $3 \mathrm{M}$, menyanyikan lagu nasional, dan menyampaikan tujuan pembelajaran. Kegiatan Inti dalam proses pembelajaran pada siklus I juga dibantu dengan menggunakan aplikasi whatsapp group dan zoom meeting. Materi yang diajarkan pada siklus I ini adalah muatan pelajaran IPS "Pemanfaatan Sumber Daya Alam Hayati" dan untuk muatan pelajaran IPA "Ciri-ciri Tanaman dan Hewan Terawat". Kegiatan yang dilakukan menggunakan prinsip Pendekatan Pembelajaran Saintifik yaitu ada $5 \mathrm{M}$ seperti mencoba, menyimak, menanya, mengkomunikasikan, dan menalar. Selain itu, kegiatan pembelajaran juga menggunakan prinsip pembelajaran 4C yaitu Communication, Creative Thinking, Critical Thinking, dan Collaboration. Dalam kegiatan inti, peneliti memberikan LKPD muatan pelajaran IPA materi "Tanaman dan Hewan Terawat". Lalu untuk muatan pelajaran IPS, peneliti memberikan soal evaluasi yang dibantu dengan aplikasi Kahoot atau aplikasi whatsapp jika peserta didik kesulitan dalam membuka link yang dibagikan. Lalu setelah melakukan kegiatan evaluasi maka peningkatan hasil belajar siswa dari Pra Siklus ke Siklus I. Jumlah siswa yang tuntas belajar pada Pra Siklus hanya 10 anak atau 34\% dan siswa yang belum tuntas berjumlah 19 anak atau $66 \%$, dengan nilai rata-rata menjadi 67,65 . Pada Siklus I hasil belajar siswa meningkat dengan nilai rata-rata menjadi 73,27 . Siswa yang tuntas belajar sebanyak 21 anak atau $72 \%$, sedangkan siswa yang belum tuntas belajarnya berjumlah 8 anak atau $28 \%$ dari 29 anak. Hasil observasi pada siklus I diperoleh gambaran tentang masih belum cukupnya pemahaman siswa terhadap materi yang diajarkan dengan menggunakan 
Pendekatan Pembelajaran Saintifik dalam pembelajarannya. Dan peneliti masih belum bisa mengkondisikan peserta didik dalam proses pembelajaran yang menggunakan aplikasi Zoom Meeting. Hal ini tampak ketika ada beberapa siswa yang masih terlihat bingung pada saat menngunakan aplikasi zoom meeting, sehingga mereka bersuara saat pembelajaran sedang berlangsung. Kegiatan perbaikan pembelajaran pada Siklus II di Kelas IV SD Negeri Cilacap 05 untuk muatan pelajaran IPS Tema 3 materi "Pemanfaatan Sumber Daya Alam Hayati", masih dilaksanakan dengan menggunakan Rencana Pelaksanaan Pembelajaran (RPP) Daring untuk alokasi waktu 2x35 menit, yang dilengkapi dengan Lembar Observasi Sikap ketika belajar dari rumah, LKPD, lembar evaluasi (Quizizz), dan Media Pembelajaran (Power Point yang berupa Video dan gambar). Tahap pelaksanaan tindakan siklus II ini dilaksanakan dalam satu kali pertemuan, dengan alokasi waktu adalah 2 x 35 menit. Perbaikan pembelajaran ini dilaksanakan pada hari Senin, 9 November 2020. Kegiatan Inti dalam proses pembelajaran pada siklus II juga dibantu dengan menggunakan aplikasi whatsapp group dan zoom meeting. Materi yang diajarkan pada siklus I ini adalah muatan pelajaran IPS "Pemanfaatan Sumber Daya Alam Hayati" dan untuk muatan pelajaran IPA "Cara Merawat Tanaman dan Hewan". Dalam kegiatan inti, peneliti memberikan LKPD muatan pelajaran IPS materi "Pemanfaatan Sumber Daya Alam Hayati", sedangkan untuk muatan pelajaran IPA materi "Membuat Peta Konsep Cara Merawat Tanaman dan Hewan".. Lalu untuk muatan pelajaran IPS, peneliti memberikan soal evaluasi yang dibantu dengan aplikasi Quizizz atau aplikasi whatsapp jika peserta didik kesulitan dalam membuka link yang dibagikan.. adanya peningkatan hasil belajar siswa dari Siklus I ke Siklus II. Jumlah siswa yang tuntas belajar pada Siklus I hanya 21 anak atau $72 \%$ dan siswa yang belum tuntas berjumlah 8 anak atau $28 \%$, dengan nilai ratarata menjadi 73,27. Kemudian pada Siklus II terjadi sedikit peningkatan hasil belajar siswa yaitu nilai rata-rata kelas menjadi 88,68 . Siswa yang tuntas belajar sebanyak 27 anak atau 93\%, sedangkan siswa yang belum tuntas belajarnya berjumlah 2 anak atau $7 \%$ dari 29 anak. Contoh penyajian tabel dan gambar sebagai berikut.

Tabel 1. Hasil Belajar IPS Siswa Kelas IV SDN Cilacap 05

\begin{tabular}{lccc}
\hline \multicolumn{1}{c}{ Aspek } & \multicolumn{3}{c}{ Hasil Penelitian } \\
\hline & Pra Siklus & Siklus I & Siklus II \\
Prosentase Ketuntasan Siswa & $34 \%$ & $72 \%$ & $93 \%$ \\
Prosentase Ketidaktuntasan Siswa & $66 \%$ & $28 \%$ & $7 \%$ \\
Nilai Rata-rata Kelas & 67,65 & 73,27 & 88,68 \\
\hline
\end{tabular}

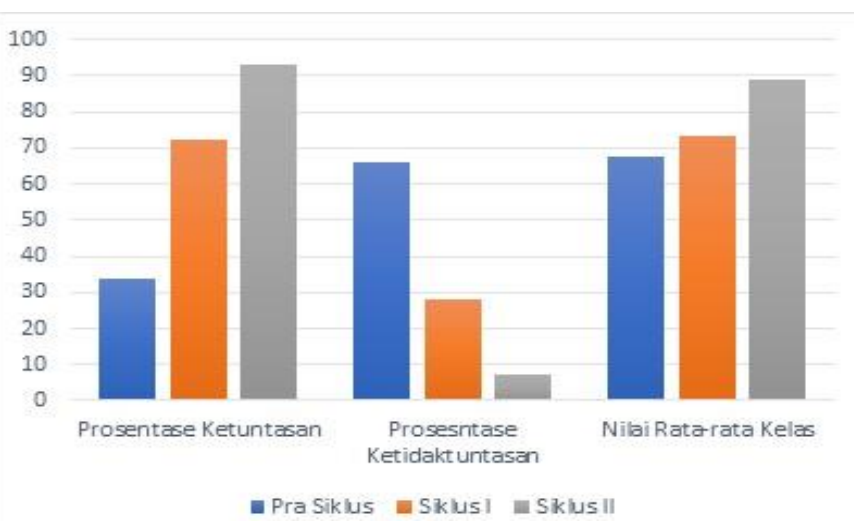

Gambar 1. Hasil Observasi Keterampilan Proses Sains 


\section{SIMPULAN}

Penerapan Pendekatan Saintifik Berbantuan dalam proses pembelajaran IPS muatan pelajaran dari Tema 3, dapat meningkatkan hasil belajar siswa kelas IV SD Negeri Cilacap 05. Hal ini dapat ditunjukkan dengan meningkatnya nilai belajar siswa dari siklus I sampai dengan siklus II. Pada siklus I diperoleh nilai rata-rata 73.27 dengan ketuntasan belajar adalah $72 \%$, dan pada siklus II diperoleh nilai rata-rata 88.68 dengan ketuntasan belajarnya adalah $93 \%$. Berdasarkan uraian di atas, maka dapat ditarik kesimpulan bahwa dengan menerapkan Pendekatan Saintifik Berbantuan dalam proses pembelajaran IPS muatan pelajaran dari Tema 3, dapat meningkatkan hasil belajar siswa kelas IV SD Negeri Cilacap 05. Jadi, hipotesis yang penulis ajukan dalam penelitian tindakan kelas ini benar-benar terbukti.

\section{DAFTAR PUSTAKA}

Arikunto, Suhardjono dan Supardi. 2006. Penelitian Tindakan Kelas. Jakarta: Bumi Aksara.

Aqib, Zainal, dkk. 2011. Penelitian Tindakan Kelas untuk Guru SD, SLB, dan TK. Bandung: Yrama Widya.

Hamalik, Oemar. 2001. Psikilogi Belajar dan Mengajar. Bandung : Sinar Baru Algensindo.

Hosnan, M. 2014. Pendekatan Saintifik dan Kontekstual. Jakarta: Ghalia Indonesia.

Kevin. 2020. Alasan Zoom Banyak Dipakai untuk Rapat Hingga Kuliah dari Rumah. 24 Maret 08:02. Tekno.compas.com

Mandy, Archibald, Rachel dan Mavourneen. 2019. Menggunakan Zoom Video Conferencing untuk Pengumpulkan Data Kualitatif: Persepsi dan Pengalaman Para Peneliti dan Peserta. Jurnal Internasional Metode Kualitatif. 11 September . https://doi.org/10.1177\%2F1609406919874596.

Nursid Sumaatmadja. 1980. Metodologi Pengajaran IImu Sosial (IPS). Bandung: Alumni.

Ristasa, Rusna dan Prayitno. (2006). Panduan Penulisan Laporan Perbaikan Pembelajaran (Penelitian Tindakan Kelas). Purwokerto : UPBJJ UT Purwokerto.

Ridwan Abdulloh Sani. 2014. Pembelajaran Saintific untuk Implementasi Kurikulum 2013, Jakarta : PT. Bumi Aksara.

Sudjana, Nana. 2011. Penilaian Hasil Proses Belajar Mengajar. Bandung: PT Remaja Rosdakarya.

Susialana, R, \& Insan H. 2013. Pendekatan Saintifik dalam Implementasi Kurikulum 2013 Berdasarkan Kajian Teori Psikologi Belajar. Jurnal Universitas Pendidikan Indonesia, 183-193.

Yohana chandra dan Munoto. 2018. Pengembangan Perangkat Pembelajaran Menggunakan Model Pembelajaran Langsung Dengan Media ZoomingUserInterface Pada Mata Pelajaran Perekayasaan Sistem Antena Kelas XI SMKN3 Surabaya. Jurnal Pendidikan Teknik ElektroVol.7 No. 1.Hal 87-9

Zaenal, A. (2011). Buku Pintar Google. Penerbit Media Kita. Jakarta Internet 